\title{
Voltammetric determination of ascorbic acid using carbon paste electrode in ginger samples from selected areas of Ethiopia
}

\author{
Alemu Tesfaye* and Mulunesh Asaye \\ Chemistry Department, College of Science, Bahir Dar University, PO Box 79, Bahir \\ Dar, Ethiopia
}

\begin{abstract}
Carbon paste electrode was prepared for the determination of ascorbic acid in ginger (Zingiber officinale) samples from three ginger growing areas (Chilga, Tepi and Dale Sadi) in Ethiopia. The effect of $\mathrm{pH}$ on the oxidation response of ascorbic acid in $0.1 \mathrm{M}$ phosphate buffer was investigated and $\mathrm{pH} 2$ was chosen as an optimum value. The oxidation response of ascorbic acid was predominantly diffusion-controlled reaction with a better determination coefficient $\mathrm{R}^{2}=0.9945$ on the plot of anodic peak current $v s$ square root of scan rate. A square wave amplitude of $45 \mathrm{mV}$, step potential of $7.0 \mathrm{mV}$ and frequency of $25 \mathrm{~Hz}$ were chosen as optimum values. Linear calibration curve in the range of $0.1-8.0 \mathrm{mM}$ of ascorbic acid standard in $\mathrm{pH} 2$ phosphate buffer solution was obtained with a determination coefficient of 0.998 . The amount of ascorbic acid detected in ginger samples collected from the three areas, Chilga was 6.85, Tepi was 6.59 and Dale Sadi was $6.54 \mathrm{mg} / \mathrm{g}$ of ginger powder. Percentage recovery in the range of $93 \%$ and $100 \%$ was validated for the applicability of the method for the quantitative determination of ascorbic acid in ginger samples. According to Health Canada dietary reference intakes, the maximum amount of ginger powder recommended intake for adult males in Chilga was 13.1, in Tepi 13.7 and in Dale Sadi $13.8 \mathrm{~g} / \mathrm{day}$.
\end{abstract}

Keywords: Ascorbic acid, Carbon paste electrode, Ginger, Voltammetric technique DOI: https://dx.doi.org/10.4314/ejst.v14i1.2

\section{INTRODUCTION}

Ginger (Zingiber officinale) is a widely used constituent of diets worldwide. It has been commonly consumed as a spice in a variety of beverages, food, and herbal medicine for a long time. Historically, ginger has a long tradition of being very effective in alleviating various common diseases such as arthritis

*Corresponding author: alexata16@gmail.com

(C) This is an Open Access article distributed under the terms of the Creative Commons Attribution License (http://creativecommons.org/licenses/CC BY4.0) 
pain, headache, cold, nausea, and vomiting during pregnancy (Chaiyakunapruk et al., 2006; Lete and Allué, 2016; Mao et al., 2019). In addition, it can be used to alleviate dyspepsia, constipation and gastric ulcer (Chaiyakunapruk et al., 2006; Haniadka et al., 2013). Ginger is reach in various constituents like, phenolic compounds, terpenes, polysaccharides, lipids, organic acids and raw fibers (Adel and Prakash, 2011; Mao et al., 2019). One of these chemical constituents is ascorbic acid (AA) (Scheme 1).

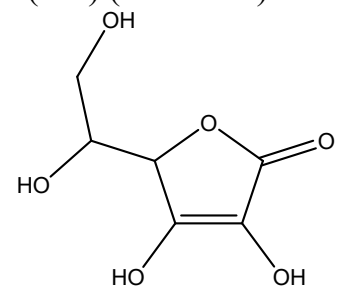

Scheme 1. The chemical structure of ascorbic acid

Ascorbic acid, or vitamin $\mathrm{C}$, is a water-soluble antioxidant that participates in many biochemical reactions and it is naturally present in many fruits and vegetables and it is available as a dietary supplement. AA with other additives, like sulfite, is widely used in various industries, mainly due to its antioxidant properties, extending the shelf life of food and beverages by inhibiting the growth of bacteria (Sartori and Fatibello, 2012).

Though most animals are able to endogenously synthesize large quantities of AA, humans do not have the capability to synthesize it (Li and Schellhorn, 2007) and yet, it has many roles and has been linked to impressive health benefits. Hence, the requirement of ascorbic acid is contented by natural source supplements and addition of it in the dietary foods. Some of impressive AA benefits are it can manage high blood pressure, reduce blood uric acid levels and help prevent gout attacks, and prevent common cold (Goodwin et al., 1983; André et al., 2010). AA also plays an important role in many biological processes such as powerful antioxidant agent which fights against free-radical induced diseases, cancer prevention and immunity improvement (Erdurak et al., 2006; Kalimuthu and John, 2009).

On the other hand, lack of AA causes scurvy, a pathological condition leading to blood vessel fragility, connective tissue damage, fatigue, cancer, and, ultimately, death (Li and Schellhorn, 2007; Habibi et al., 2011). The fact that AA is water soluble and hence regularly excreted from human body owning to rapid and extensive metabolism (Sartori and Fatibello, 2012), it does not cause significant negative effect on human health. However, excessive use of AA has been reported to cause gastric irritation, and renal problems (Hodgkinson, 
1977). In some cases, excessive quantities of AA may result in the inhibition of natural processes occurring in food and can contribute to taste/aroma deterioration and kidney damage (Hodgkinson, 1977; Sartori and Fatibello, 2012). The amount of AA required in a healthy diet varies with age and gender. According to Health Canada dietary reference intakes, estimated average requirements and recommended dietary allowances, respectively are for children (ages 1-3) 13 and $15 \mathrm{mg}$, for adult females 60 and $75 \mathrm{mg}$ and for adult males 75 and $90 \mathrm{mg}$ (Health Canada dietary reference intakes, 2010). This necessitated the determination of the level of AA in the foods we take.

Many analytical methods have been used to determine ascorbic acid in different sources including pharmaceutical formulations, fruits and foods including ginger. These techniques include HPLC (Chang and Chang, 2003), liquid chromatography (Shao et al., 2010), GC-MS (Idris et al., 2019), UV-Vis (Vermeir et al., 2008) and titration (Okiei et al., 2009). However, some of these methods are time-consuming, while others are costly, require sophisticated equipment and a sample pretreatment with high skilled technician, or suffer from insufficient sensitivity or selectivity (Farghaly et al., 2014; Pisoschi et al., 2014).

In contrast to the aforementioned conventional analytical methods, electroanalytical methods are characterized by relatively cheap instrumentation, very good sensitivity with wide linear concentration ranges for both inorganic and organic compounds, rapid analysis times and simultaneous determination of several analytes, low-cost instrumentation and being environmentally friendly (Ramírez et al., 2008; Carolina et al., 2014; Farghaly et al., 2014). Determination of AA in orange, mango, kiwi, lemon, red delicious apple, green pepper, red pepper, grape, cherry, and guava using cyclic voltammetry (Okiei et al., 2009; Julia et al., 2010) were reported. However, square wave voltammetry has not been reported for the determination of AA in ginger samples from Ethiopia. The purpose of this study, therefore, was to investigate the amount of AA in ginger cultivated in different localities of Ethiopia by square wave voltammetry.

\section{MATERIALS AND METHODS}

\section{Apparatus and chemicals}

Electroanalytical digital balance (Nimbus, UK), pH meter (Denver instrument, Hungary), orbital shaker, CHI760D Electrochemical Workstation (Austin, 
USA) connected to a personal computer were used. All electrochemical experiments were performed employing a conventional three-electrode system with a carbon paste electrode as a working electrode, platinum coil as a counter electrode and $\mathrm{Ag} / \mathrm{AgCl}$ as a reference electrode. Sodium hydroxide, hydrochloric acid, sodium phosphate monobasic, sodium phosphate dibasic, $\mathrm{pH}$ standard solutions ( $\mathrm{pH} \mathrm{4,} \mathrm{pH} \mathrm{7,} \mathrm{and} \mathrm{pH} 10)$, ascorbic acid (all from Blulux chemical Ltd, India) were used. All reagents were of analytical grade and hence were used directly without further purification.

\section{Procedures}

\section{Preparation of carbon past electrode (CPE)}

Carbon paste electrode was prepared following the reported procedure (Wang et al., 2018). Briefly: The CPE was prepared by hand mixing $80 \%(\mathrm{w} / \mathrm{w})$ graphite powder with $20 \%(\mathrm{w} / \mathrm{w})$ paraffin oil. The two components were mixed for 30 minutes using mortar and pestle to make homogeneous mixture. The homogenized paste was allowed to rest for a period of $24 \mathrm{hrs}$. The paste was packed into the tip of the plastic tube. A copper wire was inserted from the backside of the plastic tube to provide electrical contact. The surface of the electrode was smoothed manually against a smooth white paper until the surface became shiny.

\section{Preparation of standard solutions}

Different $\mathrm{pH}$ (in the range of $1.0-4.0$ ) of phosphate buffer solutions were prepared by mixing equal volumes of $1.0 \mathrm{M} \mathrm{Na}_{2} \mathrm{HPO}_{4}$ and $1.0 \mathrm{M} \mathrm{NaH}_{2} \mathrm{PO}_{4}$ for working standard solution preparation. $1.0 \mathrm{M} \mathrm{NaOH}$ and $1.0 \mathrm{M} \mathrm{HCl}$ solutions were used for PBS pH adjustments. A stock solution of $50 \mathrm{mM}$ ascorbic acid was prepared by dissolving $2.20 \mathrm{~g}$ of AA with $\mathrm{pH} 2$ of $0.1 \mathrm{M}$ PBS in $250 \mathrm{ml}$ volumetric flask. Solution of AA with concentration of 0.1, 0.5, 1.0, 2.0, 4.0, 6.0 , and $8.0 \mathrm{mM}$ were prepared by serial dilution method from the stock solution.

\section{Sample collection and sample preparation}

Samples were collected from three major ginger producing areas of Ethiopia namely Chilga, Tepi, and Dale Sadi. Chilga is one of the woredas in Central Gondar Zone of Amhara Regional State, Ethiopia. It is an important stopping point on the historic Gondar to Sudan trade route, located $61 \mathrm{~km}$ away from Gondar town. The area lies at an average altitude of $1250 \mathrm{~m}$ above sea level. The annual mean temperature of the area ranges between 16 and $23{ }^{\circ} \mathrm{C}$. Tepi is located in the Sheka zone, Southern Nations, Nationalities and Peoples' Region 
(SNNPR), $596 \mathrm{~km}$ southwest of Addis Ababa with an elevation of $1097 \mathrm{~m}$ above sea level. The annual mean temperature of the area ranges between 15.1 and $27.5{ }^{\circ} \mathrm{C}$. Dale Sadi is one of the districts in Kellem Wollega Zone of Oromia Regional State. It is $510 \mathrm{~km}$ far from Addis Ababa, capital city of Ethiopia. The area lies at an average altitude of $1150 \mathrm{~m}$ above sea level. The annual mean temperature of the area ranges between 33 and $35^{\circ} \mathrm{C}$ with more agricultural crops.

In each locality, three farmlands were chosen randomly and $1.0 \mathrm{~kg}$ fresh ginger sample was collected from each farmland which then was kept separately in plastic bags and transported to the laboratory in Bahir Dar University. Each sample was deeply washed with running tap water so as to remove adsorbed soil particulates and then rinsed with distilled water. The thin outer skin of ginger samples was removed and the remaining was chopped in to thin pieces. The chopped pieces were spread onto drying trays at room temperature for four days. The dried samples were ground with a mortar and pestle; $100 \mathrm{~g}$ powdered sample was taken from each farmland ( $300 \mathrm{~g}$ in each locality) and mixed before extraction. Then $100 \mathrm{~g}$ of ginger powder was taken from each mixture in each locality and extracted two times in $800 \mathrm{~mL}$ of pH 2 PBS at room temperature using an orbital shaker, each time with $400 \mathrm{~mL}$ for 48 hours at 200 revolutions per minute. The extracts were filtered by Whatman No. 1 filter paper and were ready for the SWV analysis. Recovery test was done by taking Chilga ginger sample to validate the performance of the method used.

\section{RESULTS AND DISCUSSION}

\section{Electrochemical property of AA}

Cyclic voltammetric and square wave voltammetric techniques were used to investigate the electrochemical behavior and the amount of AA in ginger samples, respectively. Figure 1 presents cyclic voltammogram of $\mathrm{CPE}$ in $\mathrm{pH} 2$ PBS in the absence and presence of $1.0 \mathrm{mM} \mathrm{AA}$. As can be seen from the Figure, no peak was observed without AA (a) whereas an intense anodic peak was observed in the presence of $\mathrm{AA}(\mathrm{b})$. 


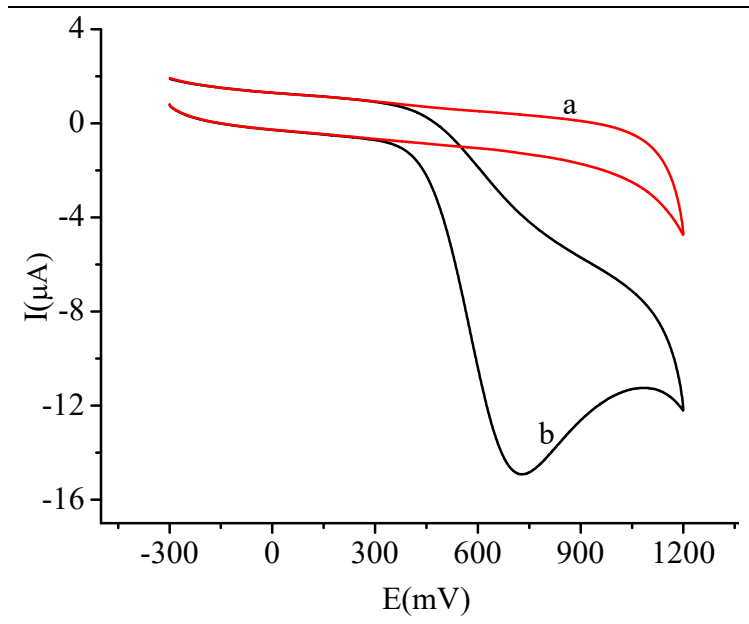

Figure 1. Cyclic voltammograms of CPE in $0.1 \mathrm{M}$ of $\mathrm{pH} 2 \mathrm{PBS}$ a) without AA and b) with $1.0 \mathrm{mM}$ AA at scan rate of $100 \mathrm{mVs}^{-1}$.

\section{Effect of pH}

It has been reported that the optimum $\mathrm{pH}$ value for AA investigation is in acidic media (Zhang et al., 2018; Zelalem Bitew and Meareg Amare, 2019). Hence, the effect of $\mathrm{pH}$ on the oxidation peak of AA for this work was investigated in the $\mathrm{pH}$ range of 1.0 to 4.0 . Figure $2 \mathrm{a}$ shows cyclic voltammograms of $1.0 \mathrm{mM}$ AA in PBS of different $\mathrm{pH}$ values. As can be seen from Figure $2 b$, anodic peak current was increased from $\mathrm{pH} 1$ to $\mathrm{pH} 2$ and decreased from $\mathrm{pH} 2$ to $\mathrm{pH} 4$. Accordingly, $\mathrm{pH} 2$ was chosen as the optimum $\mathrm{pH}$ value of the working solution.

The influence of $\mathrm{pH}$ on oxidative peak potential was also examined. The oxidation peak potential of AA shifted in the negative potential direction with increasing $\mathrm{pH}$ (Figure 2A), showing proton participation in the electrode process. A linear relationship between oxidation peak potential and $\mathrm{pH}$ was observed with a regression equation $\mathrm{Ep}(\mathrm{mV})=8.69+0.064 \mathrm{pH}\left(\mathrm{R}^{2}=0.9846\right)$ (curve a of Figure 2B). A slope of $0.064 \mathrm{~V}$ reveals that equal number of protons and electrons are involved in the oxidation process of AA within the studied $\mathrm{pH}$ range. Hence a reaction mechanism (Scheme 2) was proposed for the oxidation of AA which agrees with previous report (Sartori and Fatibello, 2012). 

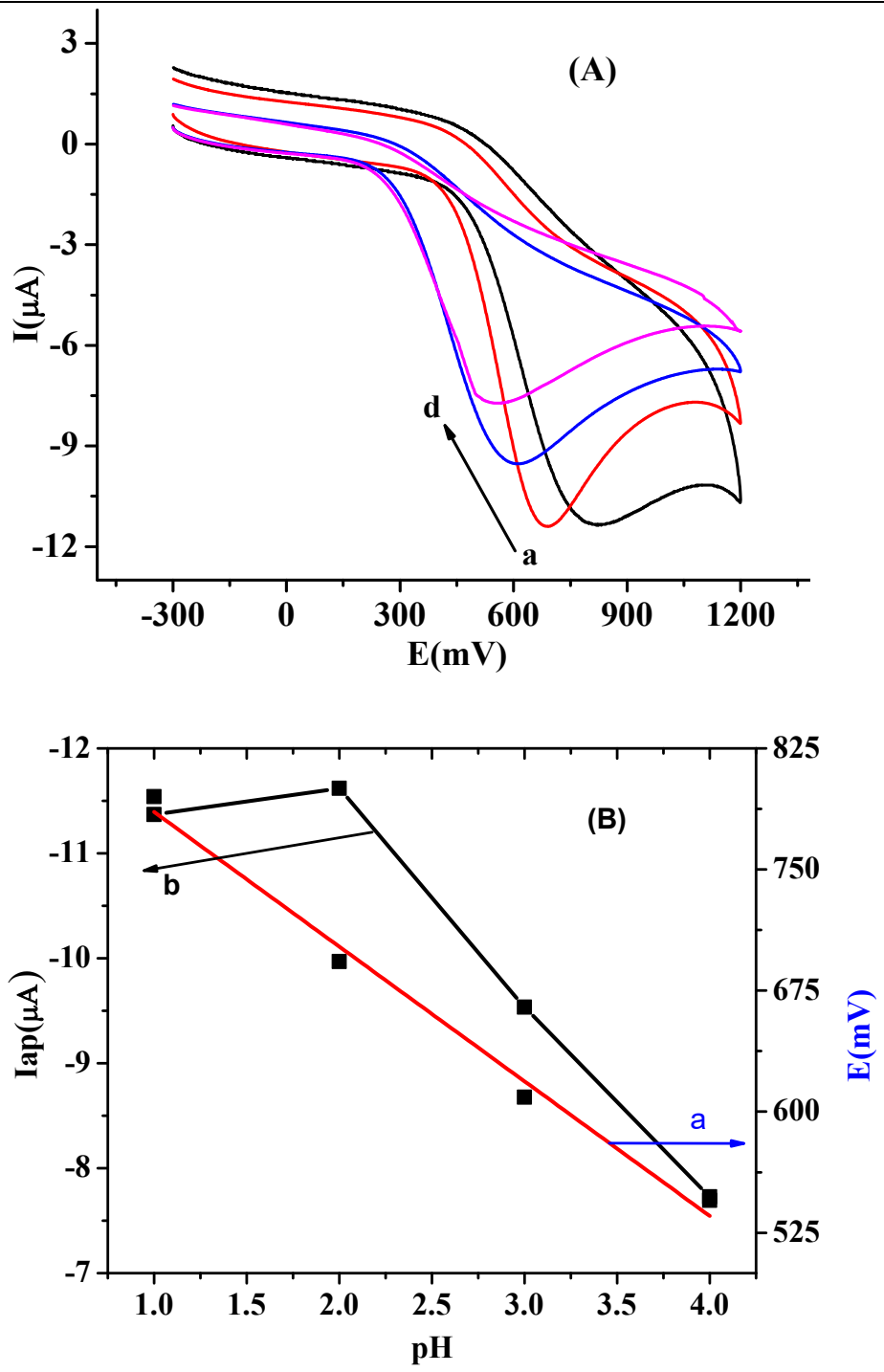

Figure 2. A) Cyclic voltammograms of CPE with $1.0 \mathrm{mM} \mathrm{AA}$ in $0.1 \mathrm{M}$ of different pH PBS (a-d: 1, 2, 3, and 4, respectively) B) Plot of (a) anodic peak potential and (b) anodic peak current $v s \mathrm{pH}$. 


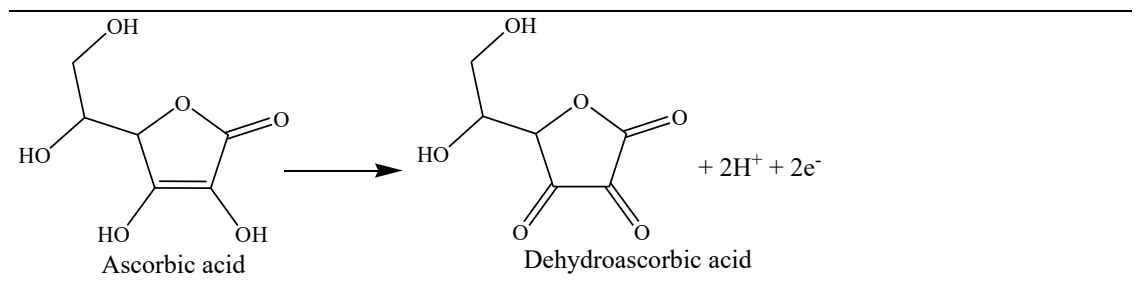

Scheme 2. Proposed mechanism of oxidation of AA.

\section{Effect of scan rate}

The effect of scan rate on the cyclic voltammetric oxidation peak current of AA was investigated in the scan rate range $20-180 \mathrm{mVs}^{-1}$. As can be seen from Figure 3, oxidation peak current increased with increasing scan rate in the entire studied range of scan rate. In addition, the observed shift of potential in the positive direction with increasing scan rate confirms the irreversibility of the oxidation of AA at the electrode surface.

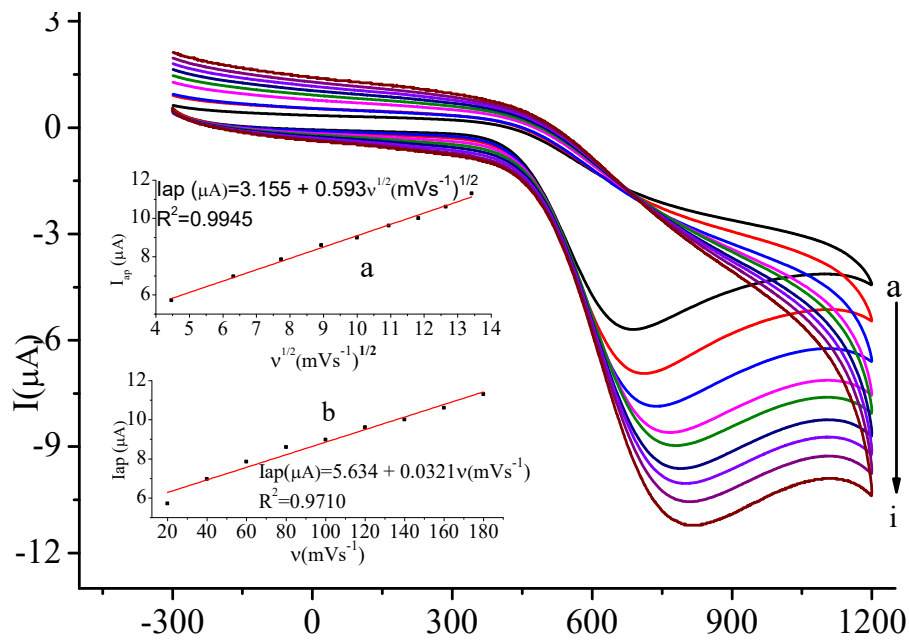

Figure 3. Cyclic voltammograms of $1.0 \mathrm{mM} \mathrm{AA}$ in $\mathrm{pH} 2 \mathrm{PBS}$ at CPE with a scan rate of (a-i: 20, 40,60, 80, 100, 120,140,160,180 $\mathrm{mVs}^{-1}$, respectively). Inset: Plot of anodic peak current of $1.0 \mathrm{mM} \mathrm{AA}$ at CPE $v s$ a) square root of scan rate and b) scan rate.

To investigate the type of reaction kinetics of AA at CPE, the dependence of peak current on the scan rate and square root of scan rate was compared. As shown in the inset of Figure 3, a better determination coefficient for the plot of current $v s$ square root of scan rate $\left(\mathrm{R}^{2}=0.9945\right.$ ) (curve a) than for plot of 
current $v s$ scan rate $\left(\mathrm{R}^{2}=0.9710\right)$ (curve b) indicated that the oxidation of AA at $\mathrm{CPE}$ is predominantly diffusion-controlled kinetics.

\section{Square wave voltammetric study of AA}

Square-wave voltammetry (SWV) is the most advanced and the most sophisticated technique in the family of pulse voltammetric techniques. SWV is effective and rapid voltammetric method with well-established advantages, including good discrimination against back- ground currents, good sensitivity and low detection limits (Laviron and Roullier, 1983; Erdurak et al., 2006). Hence, the electrochemical property of AA in $\mathrm{pH} 2 \mathrm{PBS}$ at CPE was studied by SWV method in the potential window $-300-1200 \mathrm{mV}$. As depicted in Figure 4, while no peak was observed in the absence of AA (curve a), an oxidative peak appeared at $589 \mathrm{mV}$ in response to the presence of $1.0 \mathrm{mM} \mathrm{AA}$ (curve b).

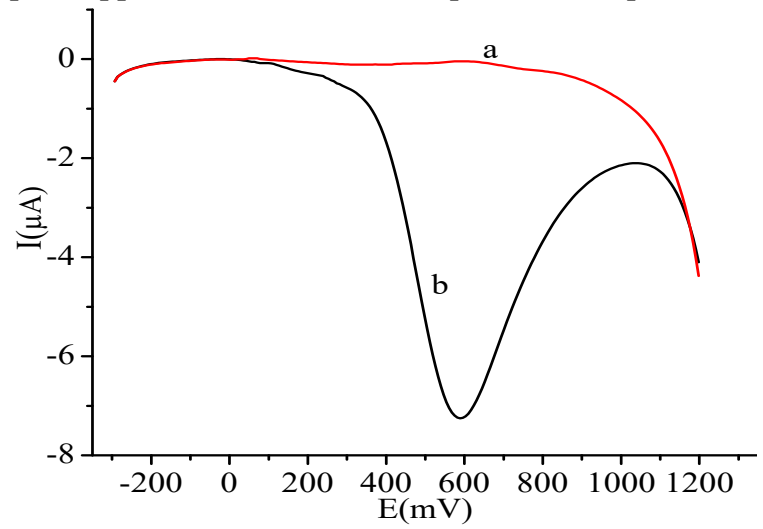

Figure 4. Square wave voltammograms of CPE in $0.1 \mathrm{M}$ of $\mathrm{pH} 2 \mathrm{PBS}$ a) without AA and b) with $1.0 \mathrm{mM} \mathrm{AA}$ at $7.0 \mathrm{mV}$ step potential, $40 \mathrm{mV}$ amplitude, and $25 \mathrm{~Hz}$ frequency.

\section{Optimization of square wave voltammetry parameters}

The dependence of oxidation peak current of AA in pH 2.0 PBS at CPE on square wave step potential, pulse amplitude and frequency were studied. The effect of square wave amplitude on the anodic peak current of AA was investigated in the range $15.0-55.0 \mathrm{mV}$ (Figure 5) at constant step potential $(4.0 \mathrm{mV})$ and square wave frequency $(15 \mathrm{~Hz})$. Upon increasing the amplitude, an increase in the peak current was observed accompanied by peak broadening when the amplitude was greater than $45 \mathrm{mV}$ (inset of Figure 5). Thus, $45 \mathrm{mV}$ was chosen as the optimum square wave amplitude. 


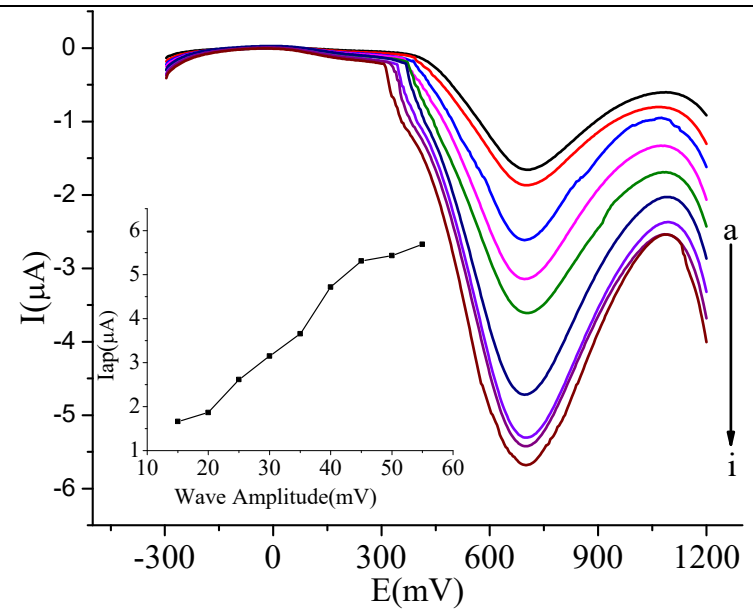

Figure 5. Square wave voltammograms of $1.0 \mathrm{mM}$ AA in $\mathrm{pH} 2 \mathrm{PBS}$ at different square wave amplitudes (a-i: 15, 20, 25, 30, 35, 40, 45, 50, $55 \mathrm{mV}$, respectively). Inset: plot of peak current $v s$ square wave amplitude.

The effect of square wave step potential on peak current of AA was also investigated in the range $3.0-9.0 \mathrm{mV}$ (Figure 6) at constant amplitude (45 $\mathrm{mV}$ ) and square wave frequency $(15 \mathrm{~Hz})$. The peak current increased with the increasing step potential. Hence, as a compromise between peak current enhancement and peak broadening with step potential increment (Inset of Figure 6), $7.0 \mathrm{mV}$ was chosen as an optimum square wave step potential.

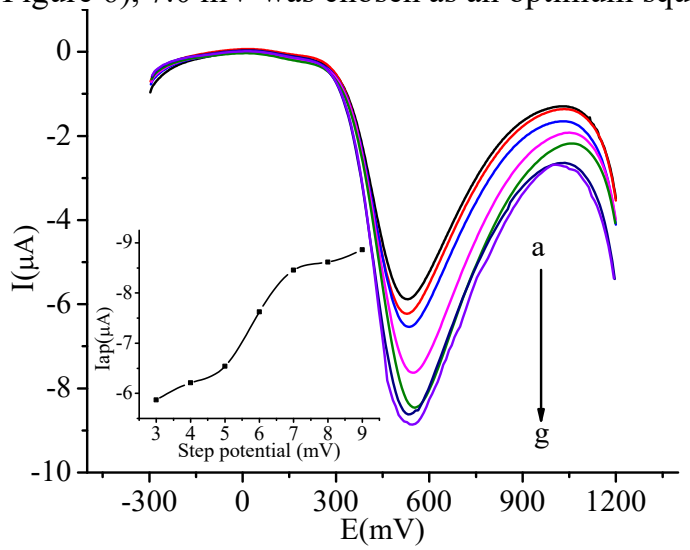

Figure 6. Square wave voltammograms of $1.0 \mathrm{mM} \mathrm{AA}$ in $\mathrm{pH} 2 \mathrm{PBS}$ at different step potentials (a-g: 3.0, 4.0, 5.0, 6.0, 7.0, 8.0, 9.0 mV, respectively), wave amplitude and wave frequency $45 \mathrm{mV}$ and $15 \mathrm{~Hz}$, respectively. Inset is plot of anodic peak current $v s$ step potential. 
By taking the optimum square wave amplitude and step potential values, square wave frequency effect on peak current was investigated in the range of $10.0-$ $35.0 \mathrm{~Hz}$. As depicted in Figure 7, peak current increment (Inset of Figure 7) accompanied by peak broadening was observed with increasing frequency. Hence, $25.0 \mathrm{~Hz}$ was chosen as an optimum square wave frequency as a compromising between peak current enhancement and peak broadening.

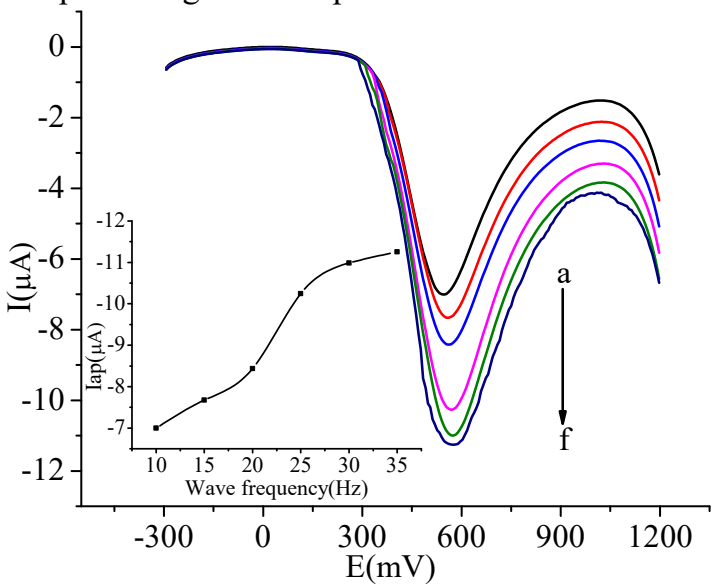

Figure 7. Square wave voltammograms of $1.0 \mathrm{mM}$ AA in $\mathrm{pH} 2 \mathrm{PBS}$ in different frequencies (a-f: $10,15,20,25,30,35 \mathrm{mV}$, respectively) at wave amplitude and step potential of 45 and $7 \mathrm{mV}$, respectively. Inset: plot of anodic peak current vs step potential.

After all the parameters were optimized, the effect of AA concentration on the square wave anodic peak current was investigated in the range of $0.1-8.0 \mathrm{mM}$. Figure 8 shows square wave voltammograms of different concentrations of AA in $\mathrm{pH} 2 \mathrm{PBS}$ at CPE. The SWV anodic peak current varied linearly with the concentration of AA in the entire studied range of concentration. The linear regression equation of anodic peak current vs AA concentration was obtained as ip $(\mu \mathrm{A})=2.318+5.643[\mathrm{AA}](\mathrm{mM})$ with a determination coefficient of 0.998 (Inset of Figure 8).

The performance of the developed method for the detection of AA was compared with other reported method (Erdurak et al., 2006). The developed method using CPE, which is the cheapest carbon-based electrode material, showed a comparable LOD $\left(2.02 \times 10^{-6} \mathrm{M}\right)$. 


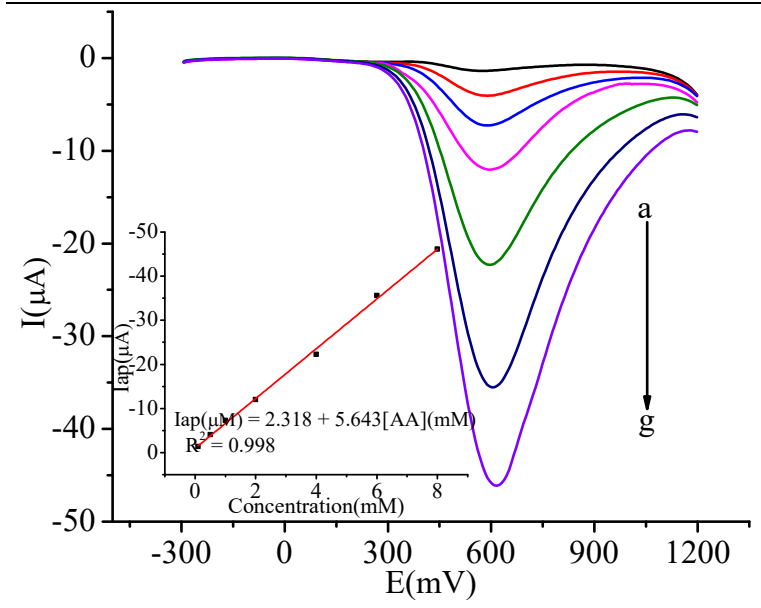

Figure 8. Square wave voltammograms of $\mathrm{CPE}$ in $\mathrm{pH} 2 \mathrm{PBS}$ containing various concentrations (a-g: $0.1,0.5,1.0,2.0,4.0,6.0,8.0 \mathrm{mM}$, respectively) of AA. Working conditions: amplitude $=45 \mathrm{mV}$, step potential $=7 \mathrm{mV}$ and frequency $=25 \mathrm{~Hz}$. Inset: Plot of anodic peak current $v s$ concentrations of AA.

\section{Real sample analyses}

Aqueous ginger extract samples were prepared following the procedure mentioned under the experimental part. To determine the concentration of AA in ginger samples cultivated in the three localities of Ethiopia, the square wave voltammetric anodic peak current for each sample was recorded which then was converted to concentration units using the regression equation obtained from the calibration curve. Figure 9 presents the square wave voltammograms of ginger extracts. As depicted from inset of Figure 9 and Table 1, the AA content of ginger samples in an increasing order is Dale Sadi, Tepi and Chilga. The observed difference in AA content could be ascribed to agronomic differences between the localities where they were cultivated. Based on the amount of AA detected in the three localities and Health Canada dietary reference intakes, the maximum amount of Chilga, Tepi, and Dale Sadi ginger powder recommended intake for adult males is $13.13,13.65$, and $13.76 \mathrm{~g} / \mathrm{day}$, respectively. On the other hand, the amount of AA detected in all the analyzed ginger extracts are found above the reported values in literature (Ogunlesi et al., 2010; Adel et al., 2011; Sangwan et al., 2014; Aluri, 2015) investigated using cyclic voltammetric and titrimetric techniques. The reason for higher values obtained in the three localities ginger extract from the reported values could be agronomical difference. 


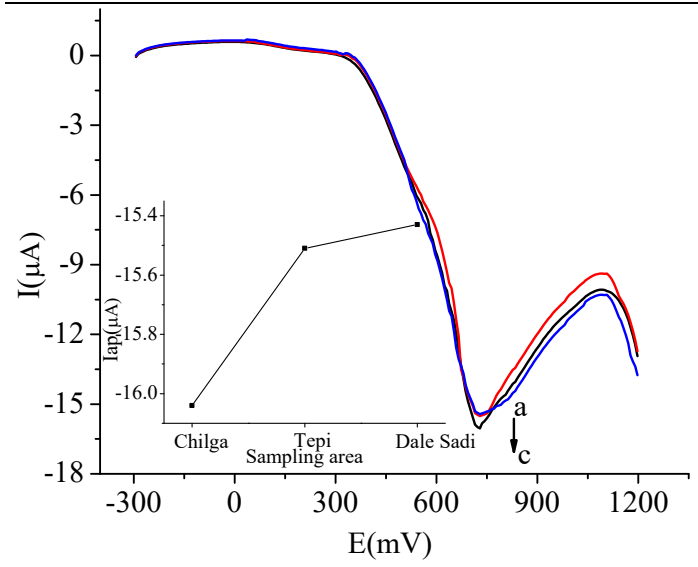

Figure 9. Square wave voltammograms of extracts of ginger sample from a) Dale Sadi, b) Tepi, and c) Chilga in pH 2 PBS at $45 \mathrm{mV}$ amplitude, $7 \mathrm{mV}$ step potential and $25 \mathrm{~Hz}$ frequency. Inset: plot of anodic peak current vs sampling site.

Table 1. The peak current, concentration of AA in the analyzed ginger extracts and mass of AA (mg/g) of powder ginger.

\begin{tabular}{llll}
\hline $\begin{array}{l}\text { Ginger sample } \\
\text { from }\end{array}$ & $\begin{array}{l}\text { Oxidation peak } \\
\text { current }(\boldsymbol{\mu A})\end{array}$ & $\begin{array}{l}\text { Concentration of } \\
\mathbf{A A}(\mathbf{m M})\end{array}$ & $\begin{array}{l}\text { Amount of AA } \\
(\mathbf{m g} / \mathbf{g})\end{array}$ \\
\hline Chilga & 16.04 & $2.432 \pm 0.006$ & $6.85 \pm 0.02$ \\
Tepi & 15.51 & $2.338 \pm 0.005$ & $6.59 \pm 0.02$ \\
Dale Sadi & 15.43 & $2.323 \pm 0.004$ & $6.54 \pm 0.01$ \\
\hline
\end{tabular}

The applicability of the method for the determination of AA in real samples was validated using its recovery for spiked standards from Chilga ginger extract, which showed highest AA level among the three analyzed ginger samples. Figure 10 presents voltammograms of Chilga ginger extract sample spiked with various volumes of $6.0 \mathrm{mM}$ standard AA solution. The observed oxidative peak current increment with increasing volume of spiked standard AA indicates the sensitivity of the method. The results summarized in Table 2 showed recovery of the method in the range of $92.89 \%$ - $100.11 \%$ confirming applicability of the method for determination of AA in ginger samples. 


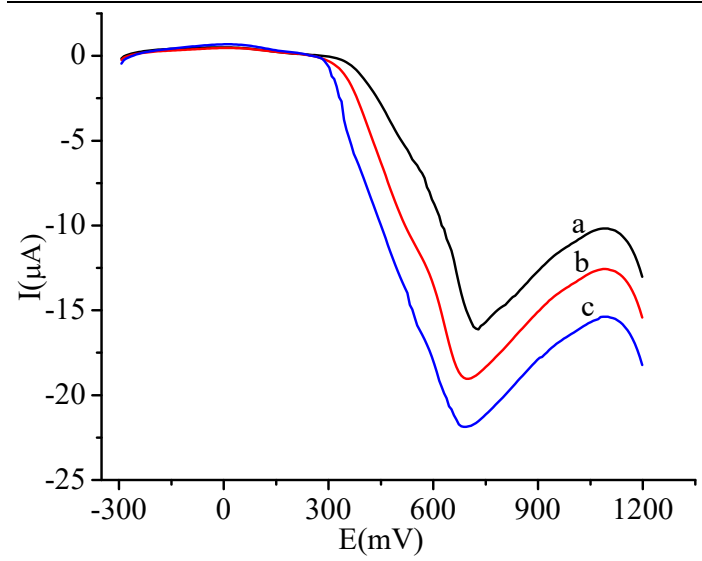

Figure 10. Square wave voltammograms of Chilga ginger extract sample spiked with various volumes (a-c: 0.0, 2.0, $4.0 \mathrm{ml}$, respectively) of $6.0 \mathrm{mM}$ standard AA solution at an amplitude of $45 \mathrm{mV}$, step potential of $7.0 \mathrm{mV}$ and frequency of $25 \mathrm{~Hz}$.

Table 2. Summary of recovery results of AA in Ginger extract sample.

\begin{tabular}{lllll}
\hline Sample & $\begin{array}{l}\text { Initial } \\
\text { Concentration } \\
(\mathbf{m g})\end{array}$ & $\begin{array}{l}\text { Spiked } \\
\text { standard } \\
(\mathbf{m g})\end{array}$ & $\begin{array}{l}\text { Found } \\
(\mathbf{m g})\end{array}$ & $\begin{array}{l}\text { Recovery } \\
(\%)\end{array}$ \\
\hline Ginger extract & 4.28 & - & - & - \\
Ginger extract & 4.28 & 2.11 & $6.24 \pm 0.04$ & $92.89 \pm 1.71$ \\
Ginger extract & 4.28 & 4.23 & $8.54 \pm 0.03$ & $100.71 \pm 0.62$ \\
\hline
\end{tabular}

Cyclic voltammetry and square wave voltammetry were used for the characterization and quantification of $\mathrm{AA}$ at carbon paste electrode, respectively. The oxidation of AA at carbon past electrode is irreversible. This was also confirmed by the oxidation potential shift over the studied range of scan rates. Oxidation potential shift with $\mathrm{pH}$ also indicated the involvement of protons in the oxidation process. The electrochemical oxidation of AA was predominantly diffusion controlled which was confirmed with a good correlation coefficient on the square root of scan rate $\left(\mathrm{R}^{2}=0.9945\right)$ than scan rate $\left(\mathrm{R}^{2}=0.9710\right)$. The linear response was obtained in the range of $2.5 \times 10^{-5}-$ $7.4 \times 10^{-4} \mathrm{M}$ with a detection limit of $2.02 \times 10^{-6} \mathrm{M}$. The highest amount of AA was obtained in the ginger sample collected from Chilga $(6.85 \mathrm{mg} / \mathrm{g})$ among the studied samples. Percentage recovery in the range $92.89 \%-100.71 \%$ showed the developed method could be competently used for the determination of AA in ginger extracts. 


\section{Conflicts of Interest}

The authors declare that there is no conflict of interest in the publication of this paper.

\section{REFERENCES}

Adel, P.S and Prakash, J. (2011). Chemical composition and antioxidant properties of ginger root (Zingiber officinale). Journal of Medicinal Plants Research 4(24): 2674-2679. DOI: 10.5897/JMPR09.464

Aluri, S. (2015). Determination of ascorbic acid content in some Indian spices. International Journal of Current Microbiology and Applied Sciences 4(8): 864-868.

André, C., Castanheira, I., Cruz, J.M., Paseiro, P and Sanches-Silva, A. (2010). Analytical strategies to evaluate antioxidants in food: a review. Trends in Food Science and Technology 21(5): 229-246. DOI: https://doi.org/10.1016/j.tifs.2009.12.003

Carolina, T.A., Barsan, M.M and Brett, C.M.A. (2014). Simple electrochemical sensor for caffeine based on carbon and Nafion-modified carbon electrodes. Food Chemistry 149: 215-220. DOI: https://doi.org/10.1016/j.foodchem.2013.10.114

Chaiyakunapruk, N., Kitikannakorn, N., Nathisuwan, S., Leeprakobboon, K and Leelasettagool, C. (2006). The efficacy of ginger for the prevention of postoperative nausea and vomiting: A meta-analysis. American Journal of Obstetrics and Gynecology 194(1): 95-99. DOI: https://doi.org/10.1016/j.ajog.2005.06.046

Chang, M.L and Chang, C.M. (2003). Simultaneous HPLC determination of hydrophilic whitening agents in cosmetic products. Journal of Pharmaceutical and Biomedical Analysis 33(4): 617626. DOI: https://doi.org/10.1016/S0731-7085(03)00343-1

Erdurak, K.C.S., Uslu, B., Dogan, B., Ozgen, U., Ozkan, S.A and Coskun, M. (2006). Anodic voltammetric behavior of ascorbic acid and its selective determination in pharmaceutical dosage forms and some Rosa species of Turkey. Journal of Analytical Chemistry 61(11): 11131120. DOI: $10.1134 / \mathrm{S} 106193480611013 \mathrm{X}$

Farghaly, O., Hameed, R.S and Abu-Nawwas, A.A.H. (2014). Analytical application using modern electrochemical techniques. International Journal of Electrochemical Science 9: 3287-3318.

Goodwin, J.S., Goodwin, J.M and Garry, P.J. (1983). Association between nutritional status and cognitive functioning in a healthy elderly population. Journal of America Medical Association 249(21): 2917-2921. DOI: 10.1001/jama.1983.03330450047024

Habibi, B., Jahanbakhshi, M and Pournaghi-Azar, M.H. (2011). Differential pulse voltammetric simultaneous determination of acetaminophen and ascorbic acid using single-walled carbon nanotube-modified carbon-ceramic electrode. Analytical Biochemistry 411(2): 167-175. DOI: https://doi.org/10.1016/j.ab.2011.01.005

Haniadka, R., Saldanha, E., Sunita, V., Palatty, P.L., Fayad, R and Baliga, M.S. (2013). A review of the gastroprotective effects of ginger (Zingiber officinale Roscoe). Food and Function 4(6): 845-855. DOI: $10.1039 / \mathrm{C} 3 \mathrm{FO} 30337 \mathrm{C}$

Health Canada Daitary reference intakes (2010). https://www.canada.ca/en/healthcanada/services/food-nutrition.html. Accessed on April 30, 2020.

Hodgkinson, A. (1977). Oxalic acid in biology and medicine. Academic Press, London.

Idris, N.A., Yasin, H.M and Usman, A. (2019). Voltammetric and spectroscopic determination of polyphenols and antioxidants in ginger (Zingiber officinale Roscoe). Heliyon 5(5): 1717. DOI: https://doi.org/10.1016/j.heliyon.2019.e01717 
Julia, R.E., Jeffrey R.F and James K.K. (2010). Determination of the vitamin C content of conventionally and organically grown fruits by cyclic voltammetry. International Journal of Electrochemical Science 5: 1464-1474.

Kalimuthu, P and John, S.A. (2009). Electropolymerized film of functionalized thiadiazole on glassy carbon electrode for the simultaneous determination of ascorbic acid, dopamine and uric acid. Bioelectrochemistry 77(1): 13-18. DOI: https://doi.org/10.1016/j.bioelechem.2009.04.010

Laviron, E and Roullier, L. (1983). Electrochemical reactions with protonations at equilibrium: Part IX. Comparison between the surface and heterogeneous electrochemical rate constants in the system phenazine/dihydrophenazine. Journal of Electroanalytical Chemistry and Interfacial Electrochemistry 157(1): 7-18. DOI: https://doi.org/10.1016/S0022-0728(83)80372-6

Lete, I and Allué, J. (2016). The effectiveness of ginger in the prevention of nausea and vomiting during pregnancy and chemotherapy. Integrative Medicine Insights 11: 11-17. DOI: 10.4137/imi.s36273

Li, Y and Schellhorn, H. E. (2007). New developments and novel therapeutic perspectives for vitamin C. The Journal of Nutrition 137(10): 2171-2184. DOI: 10.1093/jn/137.10.2171

Mao, Q.Q., Xu, X.Y., Cao, S.Y., Gan, R.Y., Corke, H., Beta, T and Li, H.B. (2019). Bioactive compounds and bioactivities of ginger (Zingiber officinale Roscoe). Foods (Basel, Switzerland) 8(6): 185-205. DOI: 10.3390/foods 8060185

Ogunlesi, M., Okiei, W., Adeyemi, A., Obakachi, V., Ikhile, M and Nkenchor, G. (2010). Vitamin $\mathrm{C}$ contents of tropical vegetables and foods determines by voltammetric and titrimetric methods and their relevance to the medicinal uses of the plants. International Journal of Electrochemical Science 5: 105-115.

Okiei, W., Ogunlesi, M., Adeyemi, A., Obakachi, V., Ikhile, M and Nkenchor, G. (2009). The voltammetric and titrimetric determination of ascorbic acid levels in tropical fruit samples. International Journal of Electrochemical Science 4: 276-287.

Pisoschi, A.M., Pop, A., Serban, A.I and Fafaneata, C. (2014). Electrochemical methods for ascorbic acid determination. Electrochimica Acta 121: 443-460. DOI: https://doi.org/10.1016/j.electacta.2013.12.127

Ramírez, B.M., Galicia, L., Gutiérrez-Granados, S., Cortes, J.S and Herrasti, P. (2008). Selective electrochemical determination of uric acid in the presence of ascorbic acid using a carbon paste electrode modified with $\beta$-Cyclodextrin. Electroanalysis 20(15): 1678-1683. DOI: 10.1002/elan.200804232

Sangwan, A., Kawatra, A and Sehgal, S. (2014). Nutritional composition of ginger powder prepared using various drying methods. Journal of Food Science and Technology 51(9): 22602262. DOI: $10.1007 / \mathrm{s} 13197-012-0703-2$

Sartori, E.R and Fatibello, F.O. (2012). Simultaneous voltammetric determination of ascorbic acid and sulfite in beverages employing a glassy carbon electrode modified with carbon nanotubes within a poly (Allylamine hydrochloride) film. Electroanalysis 24(3): 627-634. DOI: 10.1002/elan.201100691

Shao, X., Lv, L., Parks, T., Wu, H., Ho, C.T and Sang, S. (2010). Quantitative analysis of ginger components in commercial products using liquid chromatography with electrochemical array detection. Journal of Agricultural and Food Chemistry 58(24): 12608-12614. DOI: $10.1021 / \mathrm{jf} 1029256$

Vermeir, S., Hertog, M.L.A.T.M., Schenk, A., Beullens, K., Nicolaï, B.M and Lammertyn, J. (2008). Evaluation and optimization of high-throughput enzymatic assays for fast 1-ascorbic acid quantification in fruit and vegetables. Analytica Chimica Acta 618(1): 94-101. DOI: https://doi.org/10.1016/j.aca.2008.04.035

Wang, H., Qian, D., Xiao, X., Deng, C., Liao, L., Deng, J and Lin, Y.W. (2018). Preparation and application of a carbon paste electrode modified with multi-walled carbon nanotubes and boron-embedded molecularly imprinted composite membranes. Bioelectrochemistry 121: 115124. DOI: https://doi.org/10.1016/j.bioelechem.2018.01.006 
Zelalem Bitew and Meareg Amare (2019). Electrochemical determination of ascorbic acid in pharmaceutical tablets using carbon paste electrode. Organic and Medicinal Chemistry International Journal 8(5): 001-009.

Zhang, K., Zhang, N., Zhang, L., Wang, H., Shi, H and Liu, Q. (2018). Simultaneous voltammetric detection of dopamine, ascorbic acid and uric acid using a poly(2-(N-morpholine)ethane sulfonic acid)/RGO modified electrode. RSC Advances 8(10): 5280-5285. DOI: 10.1039/C7RA1326 